\title{
FROM PRIAPUS TO CYTHEREA: A SEQUENTIAL READING OF THE CATALEPTON
}

In an article published thirteen years ago, I tried to break new ground by showing that the texts transmitted under the title Catalepton as the work of Virgil can be seen to form an elaborately arranged and highly allusive book of verse written by a single author. ${ }^{1}$ This latter, I argued, was identical with the anonymous poet who, in an epilogue, represents the preceding poems as the juvenilia of the author later known for his Bucolics, Georgics and Aeneid and, consequently, is himself speaking in the alleged early works as Virgil impersonator. This anonymous poet, however, cannot rightly be labelled a literary forger, since he repeatedly and quite unmistakably recalls each of Virgil's three opera as well as other texts written after the year 19 B.c. Evidently, then, he is inviting his readers to take part in a literary lusus, one in which they are expected to be familiar not only with the texts of Bucolics, Georgics and Aeneid but also with the life of the man who wrote them. The fiction of a young Virgil is created, one who wrote his first poems - the verses referred to in the epilogue as elementa and rudis Calliope (Catal. 18[15]) - primarily under the influence of Catullus, the said poems being, with the exception of Catal. 12(9) and 16(13), epigrams. ${ }^{2}$ My interpretation has borne fruit, with Irene Peirano and Markus Stachon each devoting, in 2012 and 2014 respectively, a monograph to this approach and offering what are often very thorough analytical readings of the poems as the creations of a Virgil impersonator. ${ }^{3}$ However, neither of these two Latinists has considered one particular interpretative aspect, which I myself had only been able to introduce very briefly into my paper: the recognition that, as many more recent studies have now further corroborated, Roman poetry books were designed for linear, sequential reading, ${ }^{4}$ that they have, as it were, a story to tell. Peirano, moreover, disregards in her study the three Priapea positioned in editions before the other fifteen epigrams and shown there with their own separate numbering. ${ }^{5}$ In the manuscripts, however, the title Catalepton refers without exception to a unit comprising the three Priapea and the

\footnotetext{
${ }^{1}$ N. Holzberg, 'Impersonating young Virgil: the author of the Catalepton and his libellus', MD 52 (2004), 29-40.

${ }^{2}$ My numbering unites the Priapea and the epigrams as 1-18; the numbers shown in brackets are those conventionally used for the epigrams alone.

${ }^{3}$ I. Peirano, The Rhetoric of the Roman Fake: Latin Pseudepigrapha in Context (Cambridge and New York, 2012); M. Stachon, Tractavi monumentum aere perennius. Untersuchungen zu vergilischen und ovidischen Pseudepigraphen (Bochumer Altertumswissenschaftliches Colloquium 97) (Trier, 2014).

${ }^{4}$ See R. Höschele, Die blütenlesende Muse. Poetik und Textualität antiker Epigrammsammlungen (Classica Monacensia 37) (Tübingen, 2010) and the literature cited there.

5 Peirano (n. 3), 80 n. 23.
} 
fifteen epigrams. ${ }^{6}$ The title Priapea, found in the catalogue of the Murbach manuscripts and in some codices (for example the Graz fragment), is always attached solely to the poem Quid hoc noui est ${ }^{7}$ In the Vita Suetoniana-Donatiana (VSD), the terms Catalepton, Priapea and Epigrammata were evidently used as three different titles; the author (or his source) may not have seen that Catalepton is the title of all the poems. ${ }^{8}$ Furthermore, I should like to point out that, counted together, 'Virgil's' Priapea and epigrams come to a total of seventeen poems and so match precisely both the total of seventeen books in the real Virgil's three works and the total number of Horace's epodes, of the poems, that is, which the not-so-real Virgil quite conspicuously evokes in his own penultimate poem (Catal. 16[13]). More significantly, however, a sequential reading of the Priapea et Epigrammata can in fact build a watertight case for taking the texts to be, as it were, a composite whole, and that is what $I$ intend to argue in the rest of the article.

Roman poetry books can offer a story in the sense that the beginning and the end of a phase in the life of the poet's persona are marked by the first and last poems within a liber, by two cornerstones between which accounts of individual episodes, or reflections on such, can be positioned. The episodes are not arranged in chronological order, but are instead linked by means of associative allusions which create the impression of a linear sequence; this is especially discernible in Propertius and Ovid, both of whom plot the timeline of their erotic experiences (amores) over three books. ${ }^{9}$ The three Priapea which open 'Virgil's' Catalepton, and which we are apparently meant to suppose were written during a youth spent by the poet on his father's country estate, erect as one of the liber's two narrative cornerstones a statue of the garden god (in Catal. 2 it is made of poplar, in Catal. 3 of oak); the second supporting element is positioned in Catal. 17(14), taking the form of another statue, this time Amor, and 'Virgil' says that he will consecrate it to Cytherea if she will help complete the poem he has now begun, the Aeneid. Since no mention of work on the Bucolica and the Georgica is made in all this, ${ }^{10}$ we are probably meant to imagine that, by the time 'Virgil' had finished his Catalepton, he already had a clear vision of the epic poem he felt would be his crowning achievement, and that he never lost sight of that while writing the two opera which would actually precede it. All this would seem to mirror the perception that arose very soon after Virgil's death, when the three opera came to be seen as a triptych: in the threefold asyndetic pascua rura duces of the epitaph (VSD §36), in

\footnotetext{
${ }^{6}$ F. Zogg, 'Carmina Virgilii mitte minora, precor: Die Überlieferung der Appendix Vergiliana im Mittelalter', MLatJb 53 (2018), 27-45, at 32.

${ }^{7}$ First correctly noted by E. Gaar, 'Text und kritische Bewertung des Grazer "Vergil"-Fragments', $A A W W 90$ (1953), 188-231, then by Zogg (n. 6) and recently (10 June 2017) by Michael Reeve during an Oxford symposium on the Appendix Vergiliana. The plural could indicate that this particular poem originally or once preceded the three Priapea of the Catalepton, but was later moved. Since it stands out from the other poem as decidedly obscene, someone may have thought it better suited to the Copa, before which it stands in the Murbach catalogue (cf. Zogg [n. 6]).

${ }^{8}$ In my 2004 article (see n. 1 above), I followed those who read Catalepton (et Priapea et Epigrammata), in other words, those who take et Priapea et Epigrammata to be in apposition to Catalepton, but Reeve quite rightly observed during the Oxford symposium (see $\mathrm{n} .7$ above) that there are no brackets in medieval manuscripts.

${ }^{9}$ See N. Holzberg, Die römische Liebeselegie. Eine Einführung (Darmstadt, 20156).

${ }^{10}$ The end of Catal. 12(9), however, can be read as anticipating the Bucolics (noted by Fabian Zogg).
} 
Ovid's phrasing Tityrus et segetes Aeneiaque arma (Am. 1.15.24-5) and in the undoubtedly posthumous ille ego qui prologue to the Aeneid (VSD §42). ${ }^{11}$

The years that form what the Catalepton would have us believe was the period experienced by 'Virgil' between his childhood in the country near Mantua (Catal. 1-3) and the beginning of his work on the triptych (Catal. 17[14]) are reflected in poems 4-16, which, in turn, represent a sequence of three separate phases:

1. Catal. 4(1)-8(5): studying at a school of rhetoric in Rome;

2. Catal. 9(6)-11(8): studying under the Epicurean Siro in Naples;

3. Catal. 12(9)-16(13): writing poetry under the patronage of Messalla.

The extent to which, in my view, the Priapea offer glimpses of 'Virgil's' early, rural life in the vicinity of Mantua, ${ }^{12}$ and in what way those poems are linked to the epigrams that cover the first of the above-mentioned three phases, are both aspects I discussed at considerable length in my 2004 article, thus I can safely confine myself here to a brief summary of the salient points. The anonymous author of the Catalepton uses the Priapea to fill in the 'autobiographical' blank he saw presented by G. 4.109-15, while the rural uillula on the agellus, in which a pater lives as erus pauper with his son-in other words, Virgil, senior, with the future poet (Catal. 2.3-4 and 3.5-6)-prefigures Siro's villula and the pauper agellus to which, Catal. 11(8) tells us, the father will move after his own lands have been confiscated. 'Virgil' himself, moreover, moves from the rural garden of Catal. 3, the garden from which Priapus shuts out iuuenes, to the city-dwelling of Catal. 4(1), from which he is shut out by the uir of his puella. One addendum I should like to include now is that Catal. 1 opens the liber in a way which is to a certain extent programmatic. It enumerates the seasons, thus offering an appropriately 'Virgilian' opener, because, even if presented from Priapus' point of view, it is reminiscent of the cosmological passages in the historical Virgil's works (Ecl. 6.31-40, G. 2.475-82 and Aen. 1.742-6). In addition, it leads up to an amusing twist which has the god facing in winter the prospect of being chopped up for firewood, which sets the mood for what is to come: 'juvenilia' inspired by the muse of light entertainment and forming a stark contrast to the earnestness that characterizes the greater part of the Bucolica and the Georgica, not to mention almost the entire Aeneid.

'Virgil' presents himself in Catal. 4(1) as amator, but the term itself only appears in the next poem (5[2]), directly after Corinthiorum, the first word there. Now, as we know, a Roman poetry liber quite often shows a poem $x$ followed by a poem $y$ that immediately, in the very first line, triggers expectations which seem to be the logical consequence of poem $x$, but which are then almost immediately disappointed. ${ }^{13}$ 'Virgil's' contemporaries will likely have associated the opening words of Catal. 5 (2), Corinthiorum amator, not only with uasorum but also with scortorum, the place being famous for both its bronze (aes Corinthium) and its prostitutes, ${ }^{14}$ and so the

${ }^{11}$ See most recently B. Kayachev, 'Ille ego qui quondam: genre, date, and authorship', Vergilius 57 (2011), 75-82; C. Scheidegger Lämmle, Werkpolitik in der Antike: Studien zu Cicero, Vergil, Horaz und Ovid (Zetemata 152) (Munich, 2016), 12-18.

12 Or of Cremona (cf. Ecl. 9.28). According to VSD §6, the historical Virgil spent his initia aetatis there, and Catal. 11(8).6 assumes that the father had once owned land near Cremona.

${ }_{13}$ See e.g. the transition from Tib. 1.4.81-4 to 1.5.1-9 and Holzberg (n. 9), 83-4.

14 See R.E.H. Westendorp Boerma, P. Vergili Maronis libellus qui inscribitur Catalepton conspectu librorum, prolegomenis, notis criticis, commentario exegetico instruxit, 2 vols. (Assen, 1949-1963), 1.30 and $O C D^{4}$ s.v. 'Prostitution'. 
expectation would have been that this was the beginning of another erotic poem. ${ }^{15}$ The word that in fact follows, however, is uerborum, and we then find ourselves in a brief invective against an unnamed rhetorician who really loves his Atticisms and, 'Virgil' dryly suspects, killed his own brother with a potion of uerba. Readers who have just seen the young 'Virgil' in the role of an exclusus amator living, they must deduce, in the city will now suppose that he was attending a school of rhetoric there-after all, $V S D \S 7$ does say that he moved from northern Italy to Rome-and that he was not particularly happy with the teaching. This is later confirmed by Catal. 8(5), which, like Catal. 5(2), is written in iambi puri and in vv. 1-5, in which 'Virgil' takes his leave of the scholastici-either, that is, of the rhetoricians or of his fellow students ${ }^{16}$ because he has had enough of their empty bombast and torrents of wordiness. Before it comes to that, we find him composing in Rome an epigram (Catal. 6[3]) that bears a clear thematic resemblance to the exercises in oratory which were required of students at such schools: in it he describes how the fickle goddess Fortuna brings about the fall of a successful unnamed general. That poem, in turn, is linked to the preceding poem by way of a triggered false expectation: in Catal. 5(2) we hear of a man who has been poisoned by his brother, and the first word in Catal. 6(3), aspice, seems to suggest that what follows will be the epitaph visible on the victim's grave. ${ }^{17}$ Not what happens, of course.

Up to this point, the persons mentioned in the poems- the erus pauper of 2.4 , the pater filiusque and their uicinus diues of 3.6 and 3.20, the <puella > clausa of 4(1).2, the rhetorician and his brother in 5(2) - are never given names, and now, in Catal. 6 (3), we are similarly not told which particular general 'Virgil' might mean. Reading on, we see that the poet is always very sparing when it comes to proper names, and that this induced anonymity has method. ${ }^{18}$ Such systematics, so to speak, were probably chosen in allusion to the three points in the Bucolica at which names are not named: that of the divine iuuenis in Ecl. 1, of the puer in Ecl. 4 and of the general at the beginning of Ecl. 8. In the third of these instances, the parallel to Catalepton 6(3) is obvious, but there is something else at play here too: in the declamationes given in class by students of rhetoric the use of proper names was typically also avoided, especially if, as in Catal. 6(3), the subject was an exemplary case. ${ }^{19}$

In Catal. 8(5), 'Virgil' says his farewells not only to the scholastici but also to his friends, whom he describes as formosi (v. 7). So, during his studies-as one might expect-he has been keeping company with other young people and has also fallen in love with one or the other of those. That becomes clear in Catal. 7(4), the penultimate poem of the 'studying rhetoric' phase. In it, 'Virgil' addresses someone called Musa, declaring his undying and inextinguishable love for the man and praising his beloved's poetic skills. This poem is linked to the preceding one by the simple use in v. 1 of an expression which in a manner recalls a phrase used in the last line of Catal. 6(3): there 'Virgil' had been talking about the fallacious hour that subjugates all things mortal to its

\footnotetext{
${ }^{15}$ See the transition from Mart. 2.89 (fellator) to 2.90 (rhetor), and N. Holzberg, Martial und das antike Epigramm (Darmstadt, 2012 ${ }^{2}$ ), 82-3.

${ }^{16}$ See T. Birt, Jugendverse und Heimatpoesie Vergils. Erklärung des Catalepton (Leipzig, Berlin, 1910), 73-4 and Westendorp Boerma (n. 14), 1.111-12.

17 See Westendorp Boerma (n. 14), 1.56-7.

18 'Virgil' in fact says-well-nigh metapoetically_in Catal. 16(13).34: et ['even'] nomen adscribo tuum: cinaede Lucci.

19 On the genre, see D. van Mal-Maeder, La Fiction des déclamations (Mnemosyne Supplement 290) (Leiden, 2007).
} 
will in a momento temporis, here he discusses the uariae tempora uitae. A form of concatenatio quite similar to the 'triggering false expectations' type, which has been variously noted in Roman poetry books. ${ }^{20}$

In the poem which follows Catal. 7(4) - and there is, incidentally, an implicit verbal link between v. 7 there and v. 11 in Catal. 8(5): Phoebi chorus and Camenae-'Virgil', having first bidden the rhetoricians farewell, then his friends, announces that he now wants to seek out the beati portus and the words of Siro, that is, the teachings of Epicurean philosophy, there to free his life of all cura. As he had just assured the poet Musa in Catal. 7(4) that his own love for the latter was one that held no hope of return, and since a Sextus Sabinus is now, in Catal. 8(5), labelled his cura curarum, his distress is clearly the kind of chagrin d'amour for which Catullus and the elegiac poets also use the word cura. The final four verses of Catal. 8(5) offer indirect corroboration of this:

ite hinc, Camenae, uos quoque ite iam sane, dulces Camenae (nam fatebimur uerum, dulces fuistis), et tamen meas chartas reuisitote, sed pudenter et raro.

For Ovid, being in love and writing poetry are inextricably linked, so that any farewell to a poetic genre in which a poeta/amator speaks is also a farewell to love. ${ }^{21}$ The same applies in 'Virgil's' case. He tells the Camenae, when ordering them to leave, that they should visit his pages again, but pudenter and raro. The young poet still intends to write poems, then, but only occasionally and with propriety; pudenter would undoubtedly mean a renunciation of erotic verse and, it goes without saying, of obscenity. He has previously practised both: in Catal. 2 and 3, where he talks about Priapus' erect member, even using the vulgar term mentula twice $(2.18 ; 2.21) ; 2$ in Catal. 4(1), where he speaks as an amator exclusus; and in Catal. 7(4), when he tells a man that he loves him. Such utterances are unseemly for a follower of Epicurean philosophy, a school which, as becomes particularly evident in Lucr. 4.1073-120, declares all erotic fixations to be madness. Reading the above-cited last lines of Catal. 8(5) with that in mind and moving on to Socer beate, the opening words of the next poem, one might initially take the vocative socer to indicate that 'Virgil' has done the decent thing and married, abstaining once and for all from free love and the beautiful people; since the socer is beatus, moreover, one might instantly associate him with those who, like 'Virgil', have gathered around the beati portus. What we then get, however, is an invective against a father-in-law and a son-in-law, one Noctuinus, who, in their stupidity, have been 'pressing themselves upon' a girl-premere is used in the obscene sense here ${ }^{23}$-and the poem ends with the words gener socerque, perdidistis omnia.

${ }^{20}$ See P. Claes, Concatenatio Catulliana: A New Reading of the Carmina (Amsterdam Studies in Classical Philology 9) (Amsterdam, 2002); G. Kloss, 'Überlegungen zur Verfasserschaft und Datierung der Carmina Priapea', Hermes 131 (2003), 464-85; R. Maltby, 'Proper names as a linking device in Martial 5.43-8', in J. Booth and R. Maltby (edd.), What's in a Name? The Significance of Proper Names in Classical Latin Literature (Swansea, 2006), 159-68.

${ }^{21}$ As long since noted by scholars who do not ascribe the Catalepton to the real Virgil, there are various allusions to Ovid scattered throughout the liber; see esp. R.S. Radford, 'The language of the ps.-Vergilian Catalepton with especial reference to its Ovidian characteristics', TAPA 54 (1923), 168-86.

22 Given that 'Virgil' is at his least pudens in these two poems, Catal. 8(5).14 provides an additional argument for including the three Priapea in the liber.

${ }^{23}$ See Westendorp Boerma (n. 14), 1.135. 
These words 'Virgil' cites almost verbatim from the final verse of Catull. 29, where they stand in an invective against Caesar and Pompeius, one in which the obscene terms cinaedus, diffututus and mentula are memorably used and which the unmistakeable quotation in Catal. 9(6) will bring to mind for any lector doctus.

Obviously, the good resolution indirectly voiced by 'Virgil' in v. 14 of Catal. 8(5) about henceforth only producing verse pudenter once he has moved from the school of rhetoric to Siro's auditorium is not a resolution that he keeps. Similarly, in Catal. 10(7), the poem that follows Catal. 9(6), 'Virgil' forms a verbal link to perdidistis in Catal. 9(6).6 by twice using perdidit (10[7].2; 10[7].4): the young poet confesses to his friend Varius $^{24}$ that his, 'Virgil's', love for a young boy named Pothus has been his ruin.

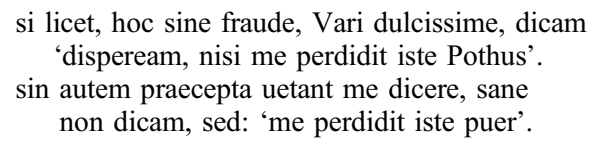

As Philip Hardie ${ }^{25}$ has demonstrated convincingly, the confession-happy 'Virgil' at least has enough Epicureanism left in him to cover his Epicurean back. Pothus, the name given to the beloved boy, can also refer to one of the gods traditionally supposed in Greco-Roman theology to stir up passionate love. The praecepta set out by Epicurus prevent 'Virgil' from saying that this has been the case for him, and so the blame is unequivocally laid at the puer's door. All that is plainly no more than humour, compounded by the ambiguity of the praecepta, which can also be read as a reference to the rules of the purists who prohibit the use of Greek words in Latin poetry (pothus with a small $p$ means 'erotic yearning'). ${ }^{26}$ Thus, 'Virgil' corrects himself, and that also in so far as he checks and changes the proper name into a puer.

In Catal. 11(8) Siro is named once more, but functions now as a possible friend in need ready to step in, if the agellus belonging to 'Virgil's' father should be confiscated: the entire family would then move into the uillula the Epicurean has on his agellus. Early allegorical readings in antiquity of Ecl. 1 are known to have assumed that the Maro family really did lose its country estate, but that it was later returned to Virgil by a iuuenis in Rome who thereby provided him with the means to write poetry, specifically bucolics. ${ }^{27}$ Since the days of Servius, if not before, the iuuenis has mostly been taken to stand for Octavian, an interpretation to which I myself also subscribe. However, the 'Virgil' of the Catalepton, speaking in the poem which directly follows Catal. 11(8) and its allusion to the confiscated lands, turns the spotlight on Messalla as a noble patron and describes at the end the kind of verse he, 'Virgil', intends henceforth to compose. It is feasible, then, that the anonymous poet of the liber wants us to believe that the iuuenis was Messalla. This latter, according to Catal. 12(9), ${ }^{28}$ himself wrote not only erotic poetry but also Greek pastoral, which, we are meant to think, could have inspired his protégé to produce bucolica. But the five Catalepton poems which follow 'Virgil's' panegyric on Messalla are in no sense

${ }^{24}$ We know from the Herculaneum papyri that the real Varius and the real Virgil belonged to the circle of friends centred around the Epicurean Philodemus; see M. Gigante, 'Vergil in the shadow of Vesuvius', in D. Armstrong, J. Fish, P.A. Johnston, M. Skinner (edd.), Vergil, Philodemus, and the Augustans (Austin, TX, 2004), 85-99.

25 'Catalepton 7', LCM 7 (1982), 50-1.

26 See Westendorp Boerma (n. 14), 1.143-4.

27 See Westendorp Boerma (n. 14), 1.156-7 and the literature cited there.

${ }^{28}$ On this poem, see now B. Kayachev, 'Catalepton 9 and Hellenistic poetry', CQ66 (2016), 180-204. 
eclogues. It therefore seems more likely that the anonymous poet is inventing an earlier patron for his Virgil, one whose fictitious place was later taken by Octavian and who was in real life the famous senator known to have supported Tibullus and Ovid. So what kind of poems has Messalla inspired the 'Virgil' of the Catalepton to produce? Well, the young poet tells us what he feels he might write at the end of Catal. 12(9), albeit in verses that are not easy to understand (vv. 59-64):

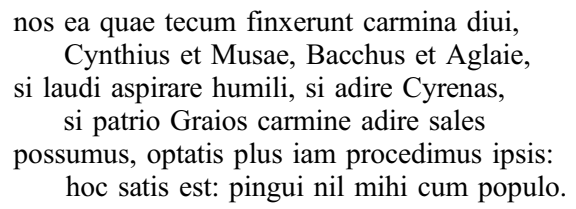

These words lead us to expect that there will now follow poems based on the tradition of Callimachean poetics and containing additional Greek 'salt'. And, indeed, the four poems presented before the final cornerstone, the prayer to Venus requesting her help with the Aeneid (Catal. 17[14]), do live up to this expectation. They are the wittiest of the collection, and one of them (Catal. 14[11]) in fact includes in its first three verses the adaptation of an epigram by Callimachus (Epigr. 61 Pf. [Anth. Pal. 7.725]), while another, Catal. 16(13), is heavily indebted to a Callimachean who also wanted nothing to do with the 'overfed' masses: Horace. ${ }^{29}$

Directly after Catal. 12(9), the eulogy on Messalla, there stands a poem in which 'Virgil' singles out for ridicule a particularly vulgar example of the 'overfed', the parvenu Sabinus. The text forms a brilliant parody on Catull. 4, with his v. 1 Phaselus ille, quem uidetis, hospites turned into Sabinus iste, quem uidetis, hospites - an almost word-for-word quotation by the poet born in Mantua of the poet born in Verona much like the gener socerque line we have already seen at the end of Catal. 9(6). Thus, the short sequence of poems which reflect 'Virgil's' Epicurean phase and the group of four poems inspired by the Greek wit of the 'poet' Messalla each begin with an unmistakeable intertextual nod in the direction of Catullus. The Sabinus epigram is followed by a dialogue in Catal. 14(11) between 'Virgil' and an Octavius, who, we are supposed at first glance to think, had died quite suddenly. The poet links the mention of Castor and Pollux in the last line of the Sabinus poem to the first line of Catal. 14 by posing the melodramatic question

quis deus, Octaui, te nobis abstulit?

But is the man really dead? 'Virgil' wonders whether it could have been all those stiff cups of unmixed wine that snatched him away, which Octavius confirms by revealing that it had happened when he was drinking with 'Virgil' and others. In much the same highfalutin way, as he then declares that there is no escaping one's fate and that the cups bear no blame, 'Virgil' laments that, with Octavius gone, Roman history too is at an end - a historian, then, this departed friend - and asks the Fates somewhat histrionically what the grievance was that had made them prevent a son from outliving his father. Interpretations of this poem would benefit greatly from a comparison with its Greek predecessor in Callimachus, but I must confine myself here, for reasons of space,

${ }^{29}$ Hor. Carm. 3.1 Odi profanum uulgus et arceo and Carm. 2.16.39-40 malignum spernere uulgus Catal. 12(9).64 pingui nil mihi cum populo. 
to the following observation: those who read the verses as a skit on a drinker rest their case on better arguments than can those readers who take the contents seriously. As once suggested by Karl Vretska, ${ }^{30}$ we are clearly meant to imagine a scene in which Octavius has fallen off the couch after drinking too much alcohol and, now a heap on the floor, jumbles his intended response to 'Virgil's' question into a sua quemque sequuntur fata instead of the intended oft-cited sua quisque fata sequitur; his father, also present on this occasion, then takes him home to sleep it off. This reading makes of the epigram a good example of biting 'salt', and that can also be said of the next poem, which begins with the word Superbe and thus picks up the superesse in the last verse of Catal. 14(11).

The pay-off line in Catal. 15(12) has, to my knowledge, only been properly understood since 2008, thanks to Lindsay Watson. ${ }^{31}$ 'Virgil' points out to Noctuinus, whom he has previously targeted in Catal. 9(6), that, if he marries the puella he has set his heart on, her father will give him his second daughter too. The poet then continues:

adeste nunc, adeste: ducit, ut decet, superbus ecce Noctuinus hirneam.

Thalassio, Thalassio, Thalassio.

The hirnea in v. 8 is usually taken to mean 'jug', and Watson, who-to my mind quite rightly_found that this made no real sense, chose to read it as a secondary form of hernia (and ducere in the sense of 'to contract'), which makes for an amusing punch line: poor Noctuinus will not only end up with two wives but also, given the double physical strain, a hernia.

One particularly witty moment in the poems 13(10)-16(13) occurs in the last of them: ${ }^{32}$ there, 'Virgil', whose historical Doppelgänger, according to VSD §11, was known as chaste Parthenias, reaches the absolute acme of salt-sprinkling. He produces an epode of forty verses which rain down such foul obscenities on someone called Luccius that earlier generations of scholars, generally only interested in establishing the authorship, struggled not a little if they decided they wanted to ascribe this poem to Virgil as well. Theodor Birt did possess the aplomb to write: 'We do not know how many liberties Virgil took in his younger days for iocatio's sake, or before the year 41.' ${ }^{33} \mathrm{He}$ even went so far as to detect obscene innuendo in vv. 24-6 (and was probably right), but only after switching briefly to Latin in order to say as much. ${ }^{34}$ In contrast, Westendorp Boerma, who penned his entire commentary on the Catalepton (without the Priapea) in Latin and only Latin, noted on vv. 24-6, 'Birtii interpretationem obscenam omnes critici iure repudiauerunt', then, on reaching what he considered the most obscene of the verses (31-2), commented, 'Pudoris causa breviter de iis agere mihi liceat', and concluded: 'Fieri non potest, ut Vergilius hunc epodum scripserit.' 35

Attentive readers will doubtless have noticed that, prior to this last paragraph, I have avoided mentioning bibliographically oriented analyses of the Catalepton, the kind, I

30 'Gedanken über den jungen Vergil', in R. Mühlher and J. Fischl (edd.), Gestalt und Wirklichkeit. Festgabe für Ferdinand Weinhandl (Berlin, 1967), 337-47, at 346-7.

31 'Of hernias and wine-jugs: Catalepton 12', Mnemosyne 61 (2008), 245-56.

32 Thalassio ... in 16(13).16 and Thalassio in 15(12).9 form the concatenatio here; see also 15(12).8 hirneam and 16(13).39 hirneosi. The name Caesar links 17(14).9 to 16(13).11.

${ }^{33}$ Birt (n. 16), 141.

34 Birt (n. 16), 157-8.

35 Westendorp Boerma (n. 14), 2.88, 2.90 and 2.77. 
mean, which were produced by Birt and Westendorp Boerma and which dominated work on the poems even until quite recently. I had intended to exclude them altogether, the approach being one which, in my opinion, can only lead one astray. Worried, however, that there might still be scholars who declare Catal. 8(5) and 11(8) to be "pearls in the mud' $^{36}$ and so happily attribute them to the historical Virgil while demoting all, or most of, the other poems to the status of inferior writing produced by various unknown poets, I decided that I should mention Westendorp Boerma's commentary after all, by way of a pre-emptive strike. The book is even more redolent than Birt's work of nineteenthcentury Romantic and historicist wishful thinking, and it is really high time that someone produced a new commentary, one which builds on the insights and findings of modern research, especially the latest work on ancient pseudepigrapha. ${ }^{37}$ Perhaps the seventeen-plus-one poems by pseudo-Virgil, texts which, like the other opuscula in the Appendix Vergiliana, abound not only in textual problems but also in puzzling, enduringly unfathomable content, would thus one day become more accessible and show us, as I believe they could, that the Catalepton is a sophisticated work of literature as well as a very funny book of poems, a liber that can best be appreciated if read as a sequential composition. $^{38}$

University of Munich

NIKLAS HOLZBERG nc.holzberg@gmail.com

${ }^{36}$ G. Maurach, 'Catal. 8 and Hellenistic poetry', AClass 12 (1969), 29-46.

${ }^{37}$ A useful interim alternative: M.G. Iodice (ed.), Appendix Vergiliana (Prefazione di Luca Canali. Classici Greci e Latini) (Milan, 2002).

${ }^{38} \mathrm{I}$ am indebted to Fabian Zogg for sharing a number of valuable observations with me. 